\title{
ALGHÓS DE UM RETORNO: CONSIDERAÇÕES SOBRE MEMÓRIA E REMINISCÊNCIA EM DOM CASMURRO E CAPITU
}

Lara Luiza Spagnol Oliveira Mestranda em Teoria da Literatura do Programa de Pós-Graduação em Estudos Literários / UFMG

\begin{abstract}
RESUMO
Propomos tratar aqui do conceito de nostalghía, de Nádia Seremetakis, no romance Dom Casmurro, de Machado de Assis, e na microssérie Capitu, de Luiz Fernando Carvalho. Memória e reminiscência, questões caras a ambas as obras que abordamos, serão aqui tomadas tendo como conceito norteador a ressignificação do termo "nostalgia”, proposta por Seremetakis.
\end{abstract}

\section{PALAVRAS-CHAVE}

Dom Casmurro, adaptação, nostalghía, memória, reminiscência

\section{INTRODUÇÃO}

Para a antropóloga grega Nádia Seremetakis, o tempo passado é uma instância que não só abarca o vivido, mas que irrompe o presente a cada instante, podendo ser experienciado novamente, provado novamente, sentido novamente. "Nothing tastes as good as the past”, afirma a autora em artigo intitulado "The memory of the senses, part I: 'Marks of the transitory””. Retornar à nossa própria história e tentar revivê-la é não só um hábito cotidiano como o mote de tantas obras artísticas, dentre as quais figuram as literárias. Acertando nosso foco na produção literária brasileira, iremos, inevitavelmente, nos encontrar com aquela que é não só uma das principais obras de nossa literatura, como também um dos mais significativos registros memoriais da ficção do Brasil: Dom Casmurro, de autoria de Machado de Assis.

A história vivida por Bentinho, personagem criado sob a saia da mãe e o quintal da encantadora vizinha, será narrada anos e anos após seu acontecimento por um

\footnotetext{
${ }^{1}$ SEREMETAKIS. The memory of the senses, part I: Marks of the Transitory, p. 1.
} 
Bentinho que já foi Bento Santiago e agora é Dom Casmurro. O passar do tempo e os acontecimentos que nele se desenrolaram foram capazes de transformar um menino ingênuo e mimado em um senhor amargurado e solitário, e é através do foco narrativo deste último que adentraremos a memória e a história desse personagem múltiplo, sob o pretexto de unir à mocidade a velhice, de atar as pontas da vida, de repassar seu trajeto e descobrir “(...) se a Capitu da Praia da Glória já estava dentro da de Mata-Cavalos”.2

A história de Dom Casmurro também foi mote para a microssérie Capitu, produzida em 2008 pela Rede Globo e dirigida por Luiz Fernando Carvalho, o qual já trabalhou com diversas adaptações literárias, como o longa-metragem Lavoura arcaica, tradução da obra homônima de Raduan Nassar. Em Capitu, o romance de Machado de Assis é recriado através dos recursos de imagem-movimento, tendo sido preservado (com raras exceções) o texto original, bem como a sequência narrativa que nos é apresentada no livro.

O que pretendemos, a partir deste artigo, é tentar analisar as formas através das quais esse transitar pela memória se faz acontecer, tanto em Dom Casmurro como em sua tradução audiovisual, Capitu. Como a reminiscência se faz ponte que dá acesso ao terreno de imagens nebulosas - fazendo uso aqui da distinção entre memória e reminiscência proposta por Aristóteles $^{3}$ - que é a memória? De quais formas essa reminiscência é ativada? Qual é o papel prestado pela imagem no contexto estudado em ambas as obras? De quais formas a recapitulação da memória pelo narrador é capaz de caracterizar o protagonista dessa narrativa de formas distintas?

Essas são algumas das questões sobre as quais pretendemos nos dedicar ao longo do desenvolvimento deste artigo.

\section{BREVES APONTAMENTOS SOBRE MEMÓRIA E REMINISCÊNCIA}

Em artigo de título “A escritura da memória: mostrar palavras e narrar imagens”, Márcio Seligmann-Silva realiza um recorte histórico acerca de uma “teoria da memória”, tomando o pensamento de Aristóteles como base para a construção do que se conceituou, até a modernidade, como memória. A distinção entre reminiscência e memória parece ser, para Seligmann-Silva, uma das mais importantes contribuições do

\footnotetext{
${ }^{2}$ MACHADO DE ASSIS. Dom Casmurro.

${ }^{3}$ ARISTÓTELES citado por SELIGMANN-SILVA. A escritura da memória: mostrar palavras e narrar imagens.
} 
filósofo grego na constituição do pensamento sobre esse tema, como podemos perceber na seguinte citação:

Em seu pequeno tratado De memoria et reminiscentia Aristóteles nota, no entanto, que a memória, devido ao seu caráter de arquivo de imagens, pertence à mesma parte da alma que a imaginação: ela é um conjunto de imagens mentais das impressões sensuais mas com um adicional temporal; trata-se de um conjunto de imagens de coisas do passado.

(...)

Aristóteles compara a imagem mental gerada pela impressão sensual a um retrato pintado que permanece na memória: "pois - ele escreveu o estímulo produzido imprime uma espécie de semelhança como percebido, exatamente como nós selamos com sinetes dos anéis” (...) Ele concebe, portanto, a formação da imagem mental como o movimento de impressão de uma imagem na cera por um anel que sela. (...)

Aristóteles distingue de modo claro entre memória e reminiscência, como o nome do seu texto o indica. A reminiscência é definida como a recuperação intencional de um conhecimento ou de uma sensação. ${ }^{4}$

Podemos afirmar, portanto, que, para Aristóteles, a memória assume o caráter de um reservatório de lembranças - logo, de um reservatório de imagens advindas das impressões e sensações do que fora vivido -, enquanto a reminiscência se caracteriza como o adentrar - intencional - nesse reservatório.

Enquanto para Aristóteles a reminiscência se caracteriza como um exercício intencional, para Nádia Seremetakis a constituição da memória traz em si algo de involuntário. Entendendo a memória como um reservatório das sensações, a antropóloga afirma:

Memory is the horizon of sensory experiences, storing and restoring the experience of each sensory dimension in another, as well as dispersing and finding sensory records outside the body in a surround of entangling objects and places. Memory and the senses are comingled in so far as they are equally involuntary experiences. ${ }^{5}$

A partir dessa perspectiva, portanto, vemos em Nádia Seremetakis uma aproximação em relação ao pensamento aristotélico, já que ambos consideram a memória como uma espécie de depósito das impressões e das experiências sensuais. O pensamento de ambos talvez se torne um pouco mais íntimo se considerarmos o fato de que, para a antropóloga, o ato de construção da memória teria em si algo de involuntário,

\footnotetext{
${ }^{4}$ SELIGMANN-SILVA. A escritura da memória: mostrar palavras e narrar imagens, p. 93-94.

${ }^{5}$ SEREMETAKIS. The memory of the senses, part I: "Marks of the transitory”, p. 8.
} 
tal qual a experiência dos sentidos, e, de forma semelhante, para Aristóteles, a construção da memória - esse desenho que é cunhado na cera - também não se dá de forma voluntária, tanto que este considera que os seres humanos possuem tipos de memórias diferentes - ceras mais rígidas ou mais moles - a depender de suas idades ou capacidades. Guardar algo no reservatório que é a memória parece ser, para ambos os pensadores, menos uma questão de intenção e mais uma questão de um acontecimento sobre o qual não temos domínio.

Postos tais esclarecimentos, talvez caiba aqui indagar novamente: se a memória constitui um horizonte que não é de nosso domínio - apesar de nele estar contido muito do que nos perpassa ou do que nos perpassou - de quais formas o acessamos? E, finalmente, como se dá o acesso a essa memória no romance Dom Casmurro e na microssérie Capitu?

\section{NOSTALGHÍA COMO REMINISCÊNCIA}

Para que possamos vislumbrar uma resposta possível para tais questões, parece interessante recorrer, novamente, a Nádia Seremetakis, focando-nos em um importante conceito por ela explicitado: a noção de nostalghía, depreendida através da análise etimológica dessa palavra, em contraposição à noção de nostalgia cotidianamente utilizada.

Segundo tal autora, o termo nostalgia, tal qual utilizado no modo norteamericano (e, muito comumente, também em nossa sociedade), não corresponde ao que uma análise dos termos componentes dessa palavra nos sugere. Sentir-se nostálgico, no modo trivial, é sentir pesar por um passado irrecuperável. Sobre essa acepção do termo, Seremetakis afirma:

This reduction of the term confines the past and removes it form any transactional and material relation to the present; the past becomes an isolatable and consumable unit of time. Nostalgia, in the American sense, freezes the past in such a manner as to preclude it from any capacity for social transformation in the present, preventing the present from establishing a dynamic perceptual relationship to its history. ${ }^{6}$

Em contraposição a esse uso do termo nostalgia, a autora propõe uma análise etimológica dos termos componentes de tal palavra, tomada aqui como uma derivação do verbo grego nostalghó. Temos, portanto, uma aglutinação formada a partir dos termos

\footnotetext{
${ }^{6}$ SEREMETAKIS. The memory of the senses, part I: marks of the transitory, p. 4.
} 
nostó e alghó. Enquanto aquele significa “eu retorno”, “eu viajo”, este significa “eu sinto dor”, “eu anseio por”. De nostó, provém o termo nostós, que significa “o retorno”, “a jornada”, e de alghó temos alghós, que remete à dor que alguém sente não só em corpo, mas também em espírito. Ao juntar ambos os termos a partir de sua significação grega, Seremetakis conclui:“Nostalghía is the desire or longing with burning pain to journey. It also evokes the sensory dimension of memory in exile and esntragement; it mixes bodily and emotional pain (...).,"

De qual maneira, portanto, a concepção que a autora propõe para a palavra nostalghía relaciona-se com o acesso à memória em Dom Casmurro e em Capitu?

A resposta a essa questão talvez resida no fato de que, o narrador do romance e, nesse caso, consequentemente, o narrador da microssérie são movidos pelo desejo (e, inevitavelmente, pela dor) de retornar a seu passado (portanto, pela nostalghía), e é, a partir daí, que ambos iniciam suas narrativas. A nostalghía funciona, aqui, como mediadora entre presente e passado, entre enunciação e memória. O nóstos desses narradores também implica um alghós, a dor corporal e sensorial, que os impulsionará para sua memória e que, também, será advinda de sua memória. A memória é, portanto, ativada através da dor causada pela lembrança do passado, a qual, não coincidentemente, muitas vezes é ativada pela lembrança corporal desse passado. Talvez poderíamos afirmar que em muitos trechos de Dom Casmurro e de Capitu a dor do retorno ocorre a partir da lembrança do corpo deixado nesse passado.

No Capítulo II de Dom Casmurro, intitulado “Do livro”, o narrador relata a seu leitor os motivos que o levaram a iniciar a empreitada de escrever seu romance de memórias. Citando:

Foi então que os bustos pintados nas paredes entraram a falar-me e a dizer-me que, uma vez que eles não alcançavam reconstituir-me os tempos idos, pegasse da pena e contasse alguns. Talvez a narração me desse a ilusão, e as sombras viessem perpassar ligeiras, como ao poeta, não o do trem, mas o do Fausto: Aí vindes outra vez, inquietas sombras?...8

A sombra, aqui, figura como uma substituta dos corpos. Capitu, Dona Glória, José Dias, todos esses corpos jaziam mortos, enterrados. Não podiam, portanto, se fazerem materialmente presente, existindo apenas pela lembrança, apenas pelas sombras,

${ }^{7}$ SEREMETAKIS. The senses still: perception and memory as material culture in modernity, p. 4.

${ }^{8}$ MACHADO DE ASSIS. Dom Casmurro, grifos no original. 
representação imaterial de um corpo. É, portanto, através dessa representação corporal ainda que não material - que o narrador inicia sua jornada rumo a suas memórias.

Adiante, no capítulo XXXIV, de título “Sou homem!”, é, simultaneamente, a lembrança do corpo de Capitu e do corpo de Bentinho que conduzirá a narrativa rumo às memórias. Lemos o relato do narrador:

Outra vez senti os beiços de Capitu. Talvez abuso um pouco das reminiscências osculares; mas a saudade é isto mesmo; é o passar e repassar das memórias antigas. Ora, de todas as daquele tempo creio que a mais doce é esta, a mais nova, a mais compreensiva, a que inteiramente me revelou a mim mesmo. Outras tenho, vastas e numerosas, doces também, de vária espécie, muitas intelectuais, igualmente intensas. Grande homem que fosse, a recordação era menor que esta. ${ }^{9}$

Nessa passagem, podemos perceber como as sensações impressas no corpo do personagem ainda criança revivem-se em sua fase adulta, como um meio que conduz ao terreno da memória; como uma reminiscência. O corpo de Bentinho rememora outro corpo - o de Capitu - e ambos se encontram no momento da enunciação do narrador. Ao sentir outra vez “os beiços de Capitu”, Dom Casmurro se torna Bentinho, embarcando em um nostós, em uma jornada rumo ao passado que, de certa forma, quebra o contínuo do tempo: a lembrança do beijo de Capitu será sempre uma lembrança nova e reveladora, que ativa as sensações do passado no presente e é capaz de fazer, ainda que por breves instantes, um personagem dar lugar a outro. Quando o narrador revive através da nostalghía - a sua infância, ele é capaz de tornar-se aquele que ele próprio já fora, pontuando sua narrativa com o encantamento e a doçura que lhe são características não enquanto o velho e solitário Casmurro, e, sim, enquanto o jovem Bentinho.

A microssérie Capitu, como já colocado anteriormente, constitui uma tradução audiovisual do romance Dom Casmurro. A atuação de Luiz Fernando Carvalho como tradutor de Machado de Assis não constitui o mote de nossa análise, porém, é nossa intenção analisar as duas obras de modo comparativo, aproximando-as a fim de perceber suas semelhanças e suas diferenças.

Para tanto, acreditamos que valha a pena recorrer a Alberto Manguel, em seu artigo "La imagen como relato", no que diz respeito às diferenças existentes entre a escrita - caso de Dom Casmurro - e a imagem - caso de Capitu:

\footnotetext{
${ }^{9}$ MACHADO DE ASSIS. Dom Casmurro.
} 
A diferencia de las imágenes, las palavras escritas fluyen constantemente más allá del encuadramiento de la página; las cubiertas del libro no demarcan las fronteras del texto (...)

Las imágenes, em cambio, se nos presentan a la conciencia de manera instantânea, contenidas por su encuadramiento - la pared de una caverna o de un museo - dentro de una superficie específica. ${ }^{10}$

Se as palavras extrapolam os limites de seu suporte, deixando seu leitor a entrever pelas linhas e, a partir daí, construir o sentido e imaginar as imagens que o texto sugere, no caso das imagens teríamos parte desse processo de construção já acabado. A Capitu que o romance Dom Casmurro nos descreve pode admitir inúmeras feições, a depender da recepção de cada um dos leitores do texto machadiano. Porém, para os espectadores da obra de Luiz Fernando Carvalho, a personagem encontra apenas duas personificações (uma em sua fase infantil e outra em sua fase adulta).

Explicitar essa distinção parece-nos necessário para que analisemos um importante trecho da microssérie de Luiz Fernando Carvalho. Trata-se de uma cena que funciona como representação de parte do primeiro trecho aqui citado, extraído do Capítulo II, de título “Do livro”. Nessa cena, ao explicitar os motivos que lhe levaram a escrever seu romance de memórias, o narrador Casmurro começa a ver as sombras perpassarem o cenário em que ele se encontra, juntamente com os ecos das vozes dos personagens que fazem parte de sua história. A representação de seu passado vai, aos poucos, tornando-se cada vez mais nítida, até que os próprios personagens são observados pelo narrador, deixando-se fitar parados, como se posassem para uma fotografia. Após a materialização corporal das sombras, Dom Casmurro, interpretado pelo ator Michel Melamed, encontra-se com Bentinho, vivido pelo jovem César Cardadeiro.

Se Machado de Assis propõe a seu leitor as sombras como representação imaterial da memória de um corpo, o diretor de Capitu oferece a seu espectador, através do trabalho dos atores, a representação corporal. O que poderia ser sugestionado pelo romance de Machado de Assis concretiza-se nas imagens construídas por Luiz Fernando Carvalho. Nessa segunda versão, a memória não é acionada somente a partir da lembrança dos corpos, e, sim, pelos corpos em si. O narrador Casmurro contracena com sua versão infantil. A modificação que o tempo causa nesse personagem é, aqui, evidente, não só por sua caracterização física, construída de modo a representar seu envelhecimento visual; quando o narrador velho encontra-se com sua versão jovem,

\footnotetext{
${ }^{10}$ MANGUEL. Leer imágenes. Uma historia privada del arte, p. 28.
} 
poder-se-ia dizer que há nos gestos de ambos - na verdade que reside no corpo, para além do discurso - muito do que caracteriza e diferencia tais personagens em épocas distintas da narrativa. Há no narrador traços da desesperança e da amargura que seu discurso e sua nostalghía em relação aos tempos idos nos deixam perceber, e há no personagem infantil algo da ingenuidade que é característica de Bentinho. A esse ponto da microssérie ambos se veem, interagem entre si e se dão as mãos. Talvez poderíamos afirmar que, em Capitu, o desejo de "restaurar na velhice a adolescência", ${ }^{11}$ ou seja, o desejo dolorido de viajar ao passado, a nostalghía, é, ainda que durante o breve período de uma cena, um desejo possível.

\section{CORPO, IMAGEM E REMINISCÊNCIA}

No capítulo “A imagem, signo da memória”, introdução da obra Imagens da memória, ${ }^{12}$ de autoria de César Guimarães, lemos que “(...) a imagem aparece ora como um reservatório de lembranças, ora como ruína de uma totalidade irrecuperável”. ${ }^{13}$ Essa imagem dúbia, capaz de funcionar ao mesmo tempo como memória e como signo do esquecimento, parece estar presente nas obras aqui analisadas através, principalmente, da personagem Capitu. A evocação da imagem da amiga e mulher de Bento sempre traz para o presente não só o que fora vivido pelos dois, mas também a dúvida em relação a sua fidelidade, a impossibilidade de reviver - talvez com olhos mais atentos - o passado. Poderíamos afirmar que, em muitos trechos, o acesso à memória nas obras que aqui analisamos se dá através da imagem corporal de Capitu. Olhos, boca, cabelos, gestos, todos esses itens perpassam o narrador Dom Casmurro ora como sombras, ora como materializações em sentido, impulsionando-o rumo a sua memória.

A presença (ou a ausência, se tratamos de sua lembrança) do corpo nessas obras é importante não só para a compreensão de um dos modos do uso da memória em tais objetos artísticos, mas também devido à presença de uma postulação, aos olhos do narrador, da verdade que Nádia Seremetakis conceituou como “extralinguística”. Segundo tal autora, "what is being said may be relativized, contradicted, or confirmed by

\footnotetext{
${ }^{11}$ MACHADO DE ASSIS. Dom Casmurro.

${ }^{12}$ GUIMARÃES. Imagens da memória: entre o legível e o visível.

${ }^{13}$ GUIMARÃES. Imagens da memória: entre o legível e o visível, p. 2.
} 
embodied acts, gestures, and sensory affects”. ${ }^{14}$ Em muitos casos, portanto, é a linguagem sensorial e corporal que prevalecerá sobre a linguagem verbalizada. Não é difícil pensarmos em passagens nas quais uma verdade extralinguística prevalece em tais obras, se estamos tratando de uma história que tem a presença da dúvida como uma de suas características mais discutidas e analisadas. O que o narrador constrói como a imagem de Capitu - e, portanto, a imagem-chave, que funciona como reminiscência e dá acesso ao terreno da memória, fazendo reverberar dali outras imagens do passado prevalece sobre o que tal personagem diz. Como proposto por Nádia Seremetakis, a verdade não reside no discurso de Capitu, e, sim, em seu corpo e em seus gestos.

Vejamos o seguinte trecho, extraído do capitulo XXVIII de Dom Casmurro:

Retórica dos namorados, dá-me uma comparação exata e poética para dizer o que foram aqueles olhos de Capitu. Não me acode imagem capaz de dizer, sem quebra da dignidade do estilo, o que eles foram e me fizeram. Olhos de ressaca?

Vá, de ressaca. É o que me dá idéia daquela feição nova. Traziam não sei que fluido misterioso e enérgico, uma força que arrastava para dentro, como a vaga que se retira da praia, nos dias de ressaca. Para não ser arrastado, agarrei-me às outras partes vizinhas, às orelhas, aos braços, aos cabelos espalhados pelos ombros; mas tão depressa buscava as pupilas, a onda que saía delas vinha crescendo, cava e escura, ameaçando envolver-me, puxar-me e tragar-me. ${ }^{15}$

A imagem de Capitu, nesse trecho como em outros, é construída pela descrição de suas características corporais. O narrador concebe seus olhos como possuidores de força própria e única - são eles que, a esse ponto, o atraem, e não a personagem como um todo. Funcionando como imagem-chave, novamente, a lembrança dos olhos serve como caminho a ser percorrido por Dom Casmurro rumo ao terreno da memória, até que, no decorrer da narrativa, seja descrita a cena do beijo entre os dois amigos.

Já no capítulo CXXIII, intitulado “Olhos de ressaca”, os olhos de Capitu, agora já adulta e esposa de Bento Santiago, serão novamente tomados, pelo narrador, quase que como parte independente da personagem. A respeito da reação da esposa no enterro do amigo (e, talvez, possível traidor) Escobar, narra-nos Dom Casmurro:

(...) Capitu olhou alguns instantes para o cadáver tão fixa, tão apaixonadamente fixa, que não admira lhe saltassem algumas lágrimas poucas e caladas...

\footnotetext{
${ }^{14}$ SEREMETAKIS. The senses still: perception and memory as material culture in modernity, p. 6.

${ }^{15}$ MACHADO DE ASSIS. Dom Casmurro.
} 
As minhas cessaram logo. Fiquei a ver as dela; Capitu enxugou-as depressa, olhando a furto para a gente que estava na sala. Redobrou de carícias para a amiga, e quis levá-la; mas o cadáver parece que a retinha também. Momento houve em que os olhos de Capitu fitaram o defunto, quais os da viúva, sem o pranto nem palavras desta, mas grandes e abertos, como a vaga do mar lá fora, como se quisesse tragar também o nadador da manhã. ${ }^{16}$

A esse ponto da narrativa, a verdade deposita-se não no corpo de Capitu, mas apenas em seus olhos. Pela perspectiva do narrador, os gestos da personagem, como as carícias para a amiga Sancha, que agora era viúva, ou o ato de querer tirá-la de perto do caixão do defunto, são desmentidos pela verdade que ele julga ver em seus olhos: a tristeza por ter perdido o amante.

A imagem corporal de Capitu também parece se sobrepor à própria personagem em alguns trechos da microssérie de Luiz Fernando Carvalho. Há, no primeiro episódio de Capitu, uma cena que pode ser tomada como uma tradução do seguinte trecho de Dom Casmurro, extraído do Capítulo XI, de título “A promessa”:

Em casa, brincava de missa, - um tanto às escondidas, porque minha mãe dizia que missa não era coisa de brincadeira. Arranjávamos um altar, Capitu e eu. Ela servia de sacristão, e alterávamos o ritual, no sentido de dividirmos a hóstia entre nós; a hóstia era sempre um doce. No tempo em que brincávamos assim, era muito comum ouvir à minha vizinha: “Hoje há missa?” Eu já sabia o que isto queria dizer, respondia afirmativamente, e ia pedir hóstia por outro nome. Voltava com ela, arranjávamos o altar, engrolávamos o latim e precipitávamos as cerimônias. Dominus, non sum dignus... Isto, que eu devia dizer três vezes, penso que só dizia uma, tal era a gulodice do padre e do sacristão. Não bebíamos vinho nem água; não tínhamos o primeiro, e a segunda viria tirar-nos o gosto do sacrifício ${ }^{17}$

Na versão audiovisual desse trecho, a performance de Bentinho tenta se aproximar do que se espera da performance de um padre diante de sua paróquia. Os gestos e o trato com as representações dos objetos sagrados - como, por exemplo, os doces que representam a hóstia - imitam os gestos paroquiais, sendo interrompidos pelas eventuais corridas atrás da amiga Capitu, afinal, trata-se de uma brincadeira. Já Capitu sustenta uma performance que contradiz suas palavras. Ao perguntar ao amigo Bentinho se "hoje há missa”, seus gestos sugerem antes um convite à dança, à brincadeira de seduzir, que ao ritual católico. Talvez o momento que condense de melhor forma nessa cena a existência, em Capitu, de uma "verdade extralinguística”, tal qual propõe Seremetakis,

\footnotetext{
${ }^{16}$ MACHADO DE ASSIS. Dom Casmurro.

${ }^{17}$ MACHADO DE ASSIS. Dom Casmurro.
} 
seja o momento da falsa comunhão. Em vez dos gestos comedidos e reflexivos que se espera de um fiel prestes a receber a hóstia, a personagem avança no biscoito e na mão do amigo, como se profanasse o ritual sagrado que ambos tentam encenar.

Retomando, novamente, a distinção entre imagem e palavra feita por Manguel, percebemos que Luiz Fernando Carvalho se posta, aqui, como um leitor de Machado de Assis, transformando o que existiria para além dos limites do texto - a própria encenação da performance de Capitu no momento da missa, inexistente no romance - em imagensmovimento.

Ainda acerca da imagem, afirma César Guimarães que essa pode se fazer presente de diversas formas, entre elas “(...) lembrança pura, de caráter mental, ou inscrita em algum suporte, tornada signo, representação verbal, pictórica, fotográfica, cinematográfica ou videográfica”. ${ }^{18}$ Tanto em Dom Casmurro quanto em Capitu, acreditamos que os exemplos apresentados apontem para o fato de que, tomada como imagem responsável pelo processo de rememoração, a representação corporal da personagem Capitu seja evocada como lembrança do narrador, inscrita nas sensações corporais deste, ou ainda como representação cinematográfica, funcione como um duplo operador em ambas as obras: conduz ao passado, ora pelo viés dolorido da dor do retorno - a ruína da totalidade irrecuperável, ${ }^{19}$ como proposto por Guimarães - ora pelo viés da dúvida insondável sobre a qual se debruça o narrador de tais obras.

\section{CONSIDERAÇÕES FINAIS}

Quando César Guimarães afirma que “a rememoração, portanto, não preenche os buracos da memória, mas sim, revela os pontos decisivos da história do sujeito”, ${ }^{20}$ sua voz encontra um eco atemporal em um narrador-personagem fictício, que tentou, através da escrita memorialística, unir as duas pontas da vida. A frustração origina-se, porém, no fato de que essa é - salvo raros momentos - uma empreitada impossível. A viagem rumo ao passado sempre trará consigo a dor, e o acesso à memória sempre será nebuloso o suficiente para não sanar as suas dúvidas. Como afirma Guimarães, Dom Casmurro não reconstituirá seu passado através de sua memória, mas, através dessas tentativas, ele narrará sua história.

\footnotetext{
${ }^{18}$ GUIMARÃES. Imagens da memória: entre o legível e o visível, p. 2.

${ }^{19}$ GUIMARÃES. Imagens da memória: entre o legível e o visível.

${ }^{20}$ GUIMARÃES. Imagens da memória: entre o legível e o visível.
} 
Por fim, em obras nas quais aquilo que é oferecido como história para o leitor tem suas raízes, justamente, nas lembranças de um narrador nostálghico e enciumado, como acreditamos ser o caso dos narradores de Dom Casmurro e Capitu, a tentativa de abordar algumas implicações da memória não pode se pretender maior que um jogar de luzes sobre certos aspectos, trechos, ou pontos que julgamos importantes. Se, para Nádia Seremetakis "memory is sensory and embeded in matter, it comes in pieces, not as totality”, 21 talvez o estudo da memória em tais obras também só possa existir se fragmentado, e se feito por meio de pequenas peças, de algumas tentativas e descobertas, e não de forma global.

\begin{abstract}
This article intends to study Nádia Seremetakis’ concept of nostalghía in Machado de Assis' novel Dom Casmurro and in one of its adaptations, the TV series Capitu, by Luiz Fernando Carvalho. Conceptual issues such as memory and reminiscence which are both related to the works addressed in this article will be studied through the reframing of the term nostalgia, as proposed by Seremetakis.
\end{abstract}

\title{
KEYWORDS
}

Dom Casmurro, adaptation, nostalghía, memory, reminiscence

\section{REFERÊNCIAS}

MACHADO DE ASSIS, Joaquim Maria. Dom Casmurro. Rio de Janeiro: Nova Aguilar, 1994. Disponível em: <http://machado.mec.gov.br/images/stories/html/romance/marm08.htm>. Acesso em: 10 mar. 2012.

CARVALHO, Luiz Fernando. Capitu. Rio de Janeiro: Rede Globo, 2008.

GUIMARÃES, César. Imagens da memória: entre o legível e o visível. Belo Horizonte: Editora UFMG, 1997.

MANGUEL, Alberto. Leer imágenes. Uma historia privada del arte. Madrid: Alianza, 2003.

SELIGMANN-SILVA, Márcio. A escritura da memória: mostrar palavras e narrar imagens. In: Terceira margem. Rio de Janeiro: Ed. UFRJ, 2002. Disponível em:

${ }^{21}$ SEREMETAKIS. The other city of silence: disaster and the petrified bodies of history, p. 310. 
$<$ http://www.letras.ufrj.br/ciencialit/terceiramargemonline/numero07/NUM07_2002.pdf >. Acesso em: 10 fev. 2012.

SEREMETAKIS, Nádia. The senses still: perception and memory as material culture in modernity. Chicago/London: The University of Chicago Press, 1996a.

SEREMETAKIS, Nádia. The memory of the senses, part I: Marks of the Transitory. In: . (Ed.). The senses still: perception and memory as material culture in modernity. Chicago/London: The University of Chicago Press, 1996b. p. 1-18.

SEREMETAKIS, Nádia. The other city of silence: disaster and the petrified bodies of history. New York: Hatije Cantz Publishers, 2000. 